\title{
REFLEXÕES SOBRE ESCRITA E PERFORMANCE EM A HORA DA ESTRELA, DE CLARICE LISPECTOR: NARRADOR PERFORMÁTICO
}

Juliana Leal

RESUMO: Pretendo com este artigo delinear a trajetória performática traçada pelo narrador de $A$ bora da estrela (1977), de Clarice Lispector, marcada por um narrar em performance que pluraliza a configuração narrativa da obra por forçar, o tempo todo, a incorporação solidária de outras vozes na conformação do texto literário como uma unidade, ainda que essa unidade seja tomada pela impossibilidade ("o oco nada") e pela incompletude. Vozes outras como a de um leitor a quem o narrador do romance se refere, vez ou outra, e com quem tenta dividir a responsabilidade do relato da experiência de narrar a vida da personagem Macabéa.

PALAVRAS-CHAVE: Escrita literária; Performance; Narrador performático; $A$ bora da estrela; Clarice Lispector.

Não se trata apenas de narrativa, é antes de tudo vida primária que respira, respira, respira. (LISPECTOR, 1998a, p. 13)

Não se conta tudo porque o tudo é um oco nada. (1998a, p. 63)

\footnotetext{
${ }^{*}$ Professora Adjunta III de Literatura Latino-americana da Faculdade Interdisciplinar em Humanidades (FIH) da Universidade Federal dos Vales do Jequitinhonha e Mucuri - UFVJM - Campus de Diamantina/MG. PhD em Literatura, outras artes e mídias pela Faculdade de Letras da UFMG (2017), Doutora em Literatura Comparada (2012).
} 
Vera Casa Nova qualifica as obras de arte dos artistas brasileiros Hélio Oiticica e Lygia Clark (O Parangolé [1965], de Oiticica, e O Túnel [1993], de Clark) como um "espaço social", um “objeto relacional” a partir das quais os artistas "fazem do corpo-objeto de arte um vir a ser do corpo que se potencializa ou se atualiza em corpo-leitor/espectador" (2002, p. 232). Segundo Casa Nova, a noção tradicional de obra aí é questionada na medida em que apresentam o objeto de arte como algo inacabado, em construção e em processo (2002, p. 229). Para além do que isso pode significar é que, para ela, o "espectador deixa de ser estático e passa a ser cinético como o objeto de arte" (2002, p. 231). E, nessa sinestesia única, performática, construída entre “objeto(s)" e espectador(es) - no plural, já que pluralizados estão pela concepção mesma que os define - como obras abertas - inúmeras serão as configurações estruturais que terão.

Partindo da ideia de narração como exercício que se instaura em uma espacialidade porosa, em processo de feitura que, muitas vezes, borra os limites entre a narração em si e a explicitação do desejo e da necessidade do narrar (um "vir a ser da palavra"), no qual não é possível restringir o narrador como único detentor da potência criadora do texto literário, é que pretendo delinear a trajetória performática traçada pelo narrador em $A$ hora da estrela, de Clarice Lispector. Um narrar em performance que pluraliza a configuração narrativa, porque força, o tempo todo, a incorporação solidária de outras vozes na conformação do texto literário como uma unidade, especialmente a de um leitor a quem o narrador se refere, vez ou outra, e com quem tenta dividir a responsabilidade do relato da experiência de narrar a vida de uma personagem como Macabéa.

A propósito da afirmação que faz Regina Pontieri, em Clarice Lispector: uma poética do olhar, sobre o fato de que, em Lispector, a questão do sujeito/objeto, ao contrário da lógica do cogito cartesiano, "são verso e reverso da mesma realidade" (1999, p. 20), refletirei sobre a narração performática desenhada em $A$ bora da estrela, tentando elucidar seus contornos teóricos, partindo da constatação de sua não vinculação a uma prática narrativa atrelada aos moldes tradicionais que definiam a experiência a partir da ideia de que algo precisava, antes, ser vivido e acumulado para, posteriormente, ser transmitido. Lógica que 
dificultaria atrelar, de forma simultânea e a partir de uma relação de retroalimentação, o trânsito de vivências entre o que se postula, antagonicamente, como objeto e sujeito. Daí a compreensão de que

[n]a sociedade contemporânea, observamos que não só desapareceram os narradores sedentários e viajantes, mas também os artesãos. Entretanto, isto não significa a morte de todas as narrativas, mas a impossibilidade de uma determinada forma de narrar e, portanto, de viver a experiência. ${ }^{1}$ (grifo meu)

A impossibilidade do narrar, sustentada por Walter Benjamin, consequência da incomunicabilidade da experiência a quem ele atribuía a posse aos narradores tradicionais como o marinheiro comerciante e o camponês sedentário, primeiros mestres na arte de narrar, estava relacionada à extinção da "verdadeira narrativa", cuja "dimensão utilitária" pressupunha a transmissão de um saber, de uma experiência, de conselhos. Coisas que, segundo esse filósofo alemão, deixariam de ser comunicáveis e se definhariam, porque "a arte de narrar está em vias de extinção" (1994, p. 197). Problematização extensiva ao romance que, para ele, está relacionado a "um indivíduo isolado, que não pode mais falar exemplarmente sobre suas preocupações mais importantes e que não recebe conselhos nem sabe dá-los" (1994, p. 201).

Analisando o romance $A$ bora da estrela, de Clarice Lispector percebemos a presença de um narrador que, realmente, não se coloca em uma posição de conselheiro, nem de alguém autorizado a transmitir, exemplarmente, saberes ou fatos a outrem, porque admite: "[o] fato é que tenho nas minhas mãos um destino e, no entanto, não me sinto com o poder de livremente inventar: sigo uma oculta linha fatal. Sou obrigado a procurar

${ }^{1}$ PEREIRA, 2001, p. 29: “En la sociedad contemporánea, observamos que no sólo desaparecieron los narradores sedentarios y viajantes, sino también los artesanos. Sin embargo, esto no significa la muerte de todas las narrativas, sino la imposibilidad de una cierta forma de narrar y, por lo tanto, de vivir la experiencia”. 
uma verdade que me ultrapassa" (1998a, p. 21, grifo meu). Vemos, ao contrário, um narrador aberto à experiência enriquecedora e humana da alteridade, para construir uma narração de um real que lhe escapa todo o tempo, porque a relação entre quem narra e o objeto do relato transfigura aquele continuamente, transformando a possibilidade da apreensão de uma história apenas a ser transmitida em algo inviável. O que leva esse narrador a qualificar essa personagem para além do que suporia nomeá-la como “objeto”. Isso se dá, porque, segundo o narrador do romance, "a realidade lhe ultrapassa" (1998a, p. 17), ao confessar não saber o que fazer com essa narrativa por estar diante de "um personagem buliçoso nas mãos e que me escapa a cada instante querendo que eu o recupere” (1998a, p. 22, grifo meu).

Acerca da constatação dessa intransmissibilidade de fatos, encontramos, em certa passagem de $A$ hora da estrela, a seguinte confissão do narrador: "Vai ser difícil escrever esta história (...) Os fatos são sonoros mas entre os fatos há um sussurro. É o sussurro o que me impressiona” (1998a, p. 24, grifo meu). A diferenciação entre os possíveis significados desses 2 (dois) termos, "fatos" e "sussurros", talvez esteja presente nas ideias que subjazem às noções de experiência como algo passível de ser transmitido e como algo da ordem do sensitivo, dado na singularidade de uma vivência perceptivo-sensorial do irrepetível, respectivamente.

No exemplo a seguir, podemos perceber o vínculo estreito entre o narrador e a personagem Macábea: "Vejo a nordestina se olhando ao espelho e - um rufar de tambor no espelho aparece o meu rosto cansado e barbudo. Tanto nós nos intertrocamos." (1998a, p. 22, grifo meu). Alteridade com a qual o narrador construirá e vivenciará a narração do romance, situando-se num lugar precário, confuso, contraditório, embora performaticamente grávido de possibilidades discursivas para a construção de um relato. De um 
relato vivencial ${ }^{2}$ e experiencial: "Ela me incomoda tanto que fiquei oco" (1998a, p. 26, grifo meu); "ela me foge por entre os dedos" (1998a, p. 29, grifo meu).

A performatividade estruturante da narração dessa obra se dá graças aos sucessivos deslocamentos de ênfases que o narrador de $A$ hora da estrela promove. Ao se voltar para um de seus “objetos” (a personagem Macabéa), traz, também, à tona a si próprio, diluindo uma suposta relação de hierarquização ou de oposição totalizante entre narrador e personagem, favorecendo outra, de integração, a partir da qual as subjetividades ficcionais (a do narrador e a da personagem) se entre mesclam e, nesse "embate", se (re)constroem continuamente por se situarem nessa posição aberta à experiência enriquecedora e solidária das trocas, do diálogo e dos intercâmbios, como o é o delicado lugar da escassez e o da precariedade:

(...) para falar da moça tenho que não fazer a barba durante dias e adquirir olheiras escuras por dormir pouco, só cochilar de pura exaustão, sou um trabalhador manual. Além de vestir-me com roupa velha rasgada. Tudo isso para me pôr no nível da nordestina. Sabendo no entanto que talvez eu tivesse que me apresentar de modo mais convincente às sociedades que muito reclamam de quem está neste instante mesmo batendo à máquina. (1998a, p. 19-20, grifo meu)

(Esta história são apenas fatos não trabalhados de matéria-prima e que me atingem direto antes de eu pensar. Sei muita coisa que não posso dizer. Aliás pensar o quê?) (1998a, p. 69, grifo meu)

Macabéa era na verdade uma figura medieval enquanto Olímpico de Jesus se julgava peça-chave, dessas que abrem qualquer porta. Macabéa simplesmente não era técnica, ela era só ela. Não, não quero ter sentimentalismo e portanto vou cortar o coitado implícito dessa moça. Mas tenho que anotar que Macabéa nunca recebera

\footnotetext{
${ }^{2}$ Com respeito à dimensão vivencial inerente ao exercício narrativo do narrador de $A$ bora da estrela, Denise Pedron também a considera na diferenciação que faz entre os conceitos de performer e ator. Segundo ela, para o primeiro não há fingimento, uma vez que vivencia a experiência da arte a partir do seu lugar de enunciação, enquanto, para o segundo, há papéis a serem representados (2006, p. 34).
} 
uma carta em sua vida e o telefone do escritório só chamava o chefe e Glória. (1998a, p. 46-47, grifo meu)

A diluição dessa hierarquização entre a posição desse narrador que não deseja "se apresentar de modo mais convincente às sociedades", da personagem e da imagem de leitor que podemos dela abstrair pode se relacionar com o que Adorno chamou encurtamento da "distância estética" no romance contemporâneo (contextualizando o contemporâneo, aqui, a partir de exemplos de obras como as de Kafka e Proust). Segundo ele, "por meio de choques é desconstruída no leitor a tranquilidade contemplativa diante da coisa lida" já que essa "abolição da distância é um mandamento da própria forma”. Adorno parece pautar essa visão a partir da incapacidade de os narradores relatarem a experiência, tal e como nos fala Walter Benjamin, uma vez que "a atitude contemplativa tornou-se um sarcasmo sangrento, porque a permanente ameaça da catástrofe não permite mais a observação imparcial, e nem mesmo a imitação estética da situação” (ADORNO, 2003, p. 61).

O fato de o narrador clariceano admitir, reiteradas vezes, ao longo de todo o romance, a irremediável necessidade que sente de se colocar no nível da nordestina, por ela se encontrar aderida à sua existência revela, de algum modo, a destruição da possibilidade da existência e da produtividade de um exercício narrativo situado contemplativamente em relação à experiência estética. A experiência da construção narrativa, após o advento da guerra, segundo assevera Benjamin, já não pode mais ser imparcial, tampouco sujeitar-se a um monopólio enunciativo exclusivo para sua constituição e, mesmo, para sua observação/recepção. Identificamos o cultivo desse modo menos exemplar de construção narrativa nos seguintes trechos de $A$ hora da estrela, a partir dos quais é plausível perceber o vínculo relacional indelével entre personagem e narrador: "Pareço conhecer nos menores detalhes essa nordestina, pois se vivo com ela. E como muito adivinhei a seu respeito, ela se me grudou na pele qual melado pegajoso ou lama negra” (1998a, p. 21, grifo meu) e "Nestes últimos três dias, sozinho, sem personagens, despersonalizo-me e tiro-me de mim como quem tira uma roupa. Despersonalizo-me a ponto de adormecer" (1998a, p. 70, grifo meu). 
Essa atmosfera produzida, fundamentalmente, pela opção por narrar a vivência mesma da narração e não propriamente uma narração-em-si, enclausurada, como objeto, coisificada para ser apenas transmitida, propicia a consolidação de uma relação de muita proximidade e intimidade entre narrador, personagem e imagem de leitor, como é possível perceber neste trecho: "Mas não sabia enfrentar a realidade. Para ela, a realidade era demais para ser acreditada. Aliás, a palavra 'realidade' não lhe dizia nada. Nem a mim, por Deus” (1998a, p. 34, grifo meu). Isso possibilita, até mesmo, que essa narração performática também possa ser experienciada pelo seu leitor (sua imagem), quando aquele propõe a este, em razão da história de vida de Macabéa: "Será essa história um dia o meu coágulo? Que sei eu. Se há veracidade nela - e é claro que a história é verdadeira embora inventada — que cada um a reconheça em si mesmo...” (1998a, p. 12, grifo meu).

O narrador-personagem de $A$ bora da estrela se define em relação a um outro; precisamente, ao outro sobre o qual narra. No confronto com o arquivo existencial de pequenas e sucessivas tragédias vividas por Macabéa, ele se vê inevitavelmente modificado, obrigando-se a repensar a si próprio, o tempo todo: "Mas eu, que não chego a ser ela, sinto que vivo para nada. Sou gratuito e pago as contas de luz, gás e telefone. Quanto a ela, até mesmo de vez em quando ao receber o salário comprava uma rosa". (1998a, p. 32); "Devo dizer que essa moça não tem consciência de mim, se tivesse teria para quem rezar e seria a salvação. Mas eu tenho plena consciência dela: através dessa jovem dou o meu grito de horror à vida. À vida que tanto amo” (1998a, p. 33, grifo meu).

Relaciono esse processo de alteridade enunciativa, resultante do percurso trilhado pelo narrador clariceano, com as considerações feitas por Bakhtin quando defende um modo exotópico da vivência do si mesmo do autor em relação à personagem do romance, 
tecido nas linhas dos artigos "O autor e a personagem"3 e "Para uma filosofia do ato". 4 Para esse filósofo russo, o interior do si próprio se reconheceria em um âmbito exterior por meio da relação que trava com o outro. No outro (seu exterior) também haveria possibilidade de uma vivência interna, a do Ser-Evento, um vivenciar o interno do si próprio na exterioridade do outro, equidistante de um exercício de reflexão estético-ética mais essencialista. Sobre isso, diz:

Ao me vivenciar fora de mim no outro, os vivenciamentos têm uma exterioridade interior voltada para mim no outro, têm uma feição interna que posso e devo contemplar com amor, sem a esquecer, assim como não esquecemos o rosto de uma pessoa (e não do modo como recordamos uma vivência passada), devo reforçar, enformar, animar, acariciar com olhos interiores e não com olhos físicos externos. (2003, p. 93, grifo meu)

O processo enunciativo performático escolhido pela narração clariceana implica a consideração dessa operação de experimentação a partir de uma alteridade enunciativa, por meio da qual o si mesmo do narrador sai de si, olhando para o outro, Macabéa, seu "fora", para, depois, retornar, sempre modificado. E esse sair para um fora de si, errância rasurada de estranheza, surpresa e dor, em busca de si mesmo a partir do "outro", que o sujeito experimenta subjetividades que não são propriamente suas, mas que acabam por modificar as suas próprias. O narrador em performance volta para o si mesmo irremediavelmente modificado pela experiência do contato com a "outridade", pelo exercício de se redefinir a partir do que de surpreendente ela lhe revela ou detona, nesse curso de desterritorialização subjetiva. Pode-se observar isso em alguns exemplos que aparecem no transcurso da obra: “A ação desta história terá como resultado minha transfiguração em outrem e minha materialização enfim em objeto. Sim, e talvez alcance a flauta doce em que eu me enovelarei

\footnotetext{
${ }^{3}$ Este texto integra a obra Estética da criação verbal (BAKTHIN, 2003).

${ }^{4}$ Segundo vários críticos, o texto Para uma filosofia do ato deve ter sido escrito por Bakhtin entre os anos de 1920 e 1924, sendo publicado somente em 1986. Marília Amorim afirma que esse texto "permaneceu como manuscrito inacabado e sem título, até ser publicado, postumamente, na Rússia, em 1986, sob o título K filosofii postupka, com introdução de Sergei Bocharov" (s.d., p. 17).
} 
em macio cipó” (LISPECTOR, 1998a, p. 20, grifo meu) e "Apesar de eu não ter nada a ver com a moça [Macabéa], terei que me escrever todo através dela por entre espantos meus" (1998a, p. 24, grifo meu).

Essa "exterioridade interior", resultado da mirada que o narrador dá para si próprio ao mirar Macabéa (a personagem e, portanto, o outro, o “objeto”), realiza o estreitamento do vínculo performático entre narrador e personagem que se dá num espaço de performação, a partir do qual narrar o outro também potencializa a formação de textualidades do si mesmo, estabelecendo uma rede dialógica que se retroalimenta. Seria isso o nu a que se refere o narrador clariceano, quando afirma: “o que escreverei não pode ser absorvido por mentes que muito exijam e ávidas de requintes. Pois o que estarei dizendo será apenas nu” (1998a, p. 16)?

No trecho a seguir, podemos notar que o narrador clariceano é nitidamente tomado por uma sensação de esperança, após acompanhar a forte expectativa em relação ao futuro que a cartomante revelara a Macabéa, seu outro. Ele experimenta uma vivência particular, interna, por meio de um ato de identificação ativa com a vivência de sua personagem, sua alteridade, seu exterior:

Macabéa nunca tinha tido coragem de ter esperança.

Mas agora ouvia a madama como se ouvisse uma trombeta vinda dos céus - enquanto suportava uma forte taquicardia. Madama tinha razão: Jesus enfim prestava atenção nela. Seus olhos estavam arregalados por uma súbita voracidade pelo futuro (explosão). E eu também estou com esperança enfim. (1998a, p. 77, grifos meus) 
Mas, muito embora exista um elo de integração entre narrador e personagem, estruturado pelo que Bakhtin chamou de "empatia"5 da atividade estética, que resulta numa identificação ativa do "eu” com o “objeto", não há a perda dos limites que os singularizam. No jogo enunciativo da narrativa performática clariceana, mesmo que o narrador, ao "escrever" o outro (Macabéa), inscreva-se, ele continua sendo ele, mas de um modo, agora, indelevelmente diferente, pelo caráter empático inerente a esse processo de narrar o si próprio através do outro, ou, ainda, de narrar o outro passando pelo si próprio. Sobre a construção dessa relação de empatia, também denominada "identificação", vale a pena recuperar o que afirma Bakhtin:

Eu me identifico ativamente com uma individualidade e, consequentemente, eu não me perco completamente, nem perco meu lugar único do lado de fora dela, sequer por um momento. Não é o objeto que inesperadamente toma possessão de mim como alguém passivo. Sou eu que me identifico ativamente com o objeto: criar empatia é um ato meu, e apenas isso constitui sua produtividade e novidade... (s/d, p. 33, grifo meu e itálicos do original)

A conformação do núcleo relacional e comunicacional da escrita literária performática que gera lugares para encontros com a alteridade se daria a partir do delineamento do que Regina Melim denominou "espaço de performação”. Segundo ela, trata-se de uma localidade instauradora de uma estrutura relacional comunicacional (2008, p. 9) na qual, por exemplo, a imagem de leitor que pode ser extraída do romance é inserida em uma obraproposição, assim como o é, durante todo o desenrolar do romance, seu narrador. Ambos em relação ao "objeto"; isto é, Macabéa. Essa obra-proposição fundaria, concomitantemente, um espaço de criação artística e de reflexão crítica dessa criação como instância vivencial estética e ética. Vejamos este exemplo:

\footnotetext{
${ }^{5}$ Bakhtin, "[a] empatia realiza alguma coisa que não existia nem no objeto de empatia, nem em mim mesmo, antes dos atos de identificação, e através dessa alguma coisa realizada o Ser-Evento é enriquecido (isto é, ele não permanece igual a ele mesmo)" (s/d, p. 33).
} 
Embora só tivesse nela a pequena flama indispensável: um sopro de vida. (Estou passando por um pequeno inferno com esta história. Queiram os deuses que eu nunca descreva o lázaro porque senão eu me cobriria de lepra.) (Se estou demorando um pouco em fazer acontecer o que já prevejo vagamente, é porque preciso tirar vários retratos dessa alagoana. $\mathbf{E}$ também porque se houver algum leitor para essa história quero que ele se embeba da jovem assim como um pano de chão todo encharcado. A moça é uma verdade da qual eu não queria saber. Não sei a quem acusar, mas deve haver um réu.) (LISPECTOR, 1998a, p. 39, grifo meu)

Narrador e personagem, apresentados dentro dessa lógica narrativa interacional, deixariam de ser vistos como instâncias independentes e exteriores, uma em relação à outra - tal e como apregoava a noção humanística de sujeito a partir da qual a consciência do sujeito é o que lhe permitia compreender o mundo e as coisas, levando-o a dar conta, sozinho, de suas experiências subjetivas -, e se inseririam em um espaço de arena, o da performação, localidade favorecedora da realização dos atos de identificação, a partir da qual o texto-proposição, fruto da narração performática, englobaria, simultaneamente, a imagem de leitor, personagem e narrador como partícipes da obra-proposição, conformando o aspecto integrador subjacente à construção da(s) subjetividade(s) na contemporaneidade, por vezes contraditória, precária, fragmentada, confusa.

O sujeito, agora, diferentemente do eu cartesiano, essencialmente individualista e racional, percebe-se provisório e descentrado, assumindo, a partir de então, uma concepção interativa da identidade e do "eu" (junção das concepções sociológica e pós-moderna de identidade a que faz menção Stuart Hall), ao entender que sua formação só pode se dar a partir de um diálogo contínuo com outros "eus" e identidades exteriores, em movimento por vezes contraditório, variável, provisório e mal resolvido. Ele, agora, é Ser-Evento; isto é, é sujeito participante, sujeito vivo, inclinado a se (re)construir em espaços que propiciem a comunhão real com o outro e, consequentemente, consigo próprio.

A partir de uma “celebração móvel”, as identidades, segundo Hall, são formadas e transformadas continuamente, na medida em que somos interpelados e representados 
(2004, p. 10-13). A construção da "imagem de si" do narrador e da desse leitor, no romance delineadas, desse modo, segundo afirma Ana Cláudia Viegas, se dão em “permanente diálogo com o outro" (2008, p. 137), em permanente diálogo com Macabéa. Ao mesmo tempo em que fala dela (a personagem), o narrador em primeira pessoa clariceano fala de si, instaurando intenso movimento de afastamentos e aproximações sucessivas entre o si mesmo e o outro.

Isso condiz com o que teoriza Bakhtin sobre a relação entre autor e personagem, quando pautada na força organizadora da categoria axiológica do “outro”. Ele afirma que, em termos estéticos, uma relação axiológica minha em relação a mim mesmo (por exemplo, o narrador de $A$ bora da estrela consigo próprio, excluindo a presença axiológica de Macabéa) seria absolutamente improdutiva e irreal. Para esse teórico russo, o autor ocuparia uma posição responsável na conformação da unidade de uma obra artística, no entanto, "a relação esteticamente criadora com a personagem e o seu mundo é uma relação com quem tem de morrer" (2003, p. 176).

Esse aspecto integrador iluminado por esse caráter de provisoriedade e de incompletude, equidistante do sentido de deficiência, aponta para a importância ou para a inevitabilidade da acolhida de contribuições e interferências alheias na construção dos processos de subjetividade. Por essa razão, chama-me a atenção como as marcas de subjetivação (como se constroem, reconstroem, se sustentam e acolhem outras subjetivações) do narrador de $A$ bora da estrela não deixam de, em parte, definir também - ou influenciar - as que a imagem do leitor construída na obra poderia produzir a respeito da personagem principal do romance e, naturalmente, sobre si próprio. Tal e como faz o narrador do referido romance.

As marcas de subjetivação no romance clariceano, inseridas nessa lógica narrativa performática acolhedora do outro como potência discursiva e vivencial e tomada em um espaço de performação, mina qualquer possibilidade da exemplaridade da narração tradicional, porque o relato não mais carrega conteúdos prévios, mas é via de acesso a domínios imprevisíveis da existência humana, no diálogo instaurado do si próprio com a alteridade. 
Nesse trecho, o narrador de $A$ bora da estrela se pergunta: "É assim que se escreve? Não, não é acumulando e sim desnudando" (LISPECTOR, 1998a, p. 82, grifo meu). Processo mais ou menos semelhante experiencia o poeta Ollan, do conto "El espejo y la máscara" de Borges que, à medida que alcança a narração perfeita, também vai se implicando corporeamente e sendo tomado por algo que lhe contagia à revelia de sua vontade, até vir a falecer.

Por essa razão, o narrador clariceano admite, ao longo de todo o romance: "Bem sei que é assustador sair de si mesmo, mas tudo o que é novo assusta” (1998a, p. 30, grifo meu); "Não, não quero ter sentimentalismo e portanto vou cortar o coitado implícito dessa moça" (1998a, p. 46) e "Mas a história de Macabéa tem que sair senão eu estouro" (1998a, p. 47, grifo meu). Sensações igualmente vivenciadas por Ollan durante suas tentativas em construir os relatos solicitados pelo monarca. Este, no entanto, "estoura”, de fato, à medida que vai se envolvendo com o terceiro relato por ele (só por ele?), finalmente, elaborado, diferentemente do que ocorre com o narrador de $A$ hora da estrela, que passa a ter consciência da possibilidade de sua morte ao mesmo tempo em que demonstra uma inclinação, tímida, embora significativa, para a experiência imprevisível da vida futura:

E agora - agora só me resta acender um cigarro e ir para casa. Meu Deus, só agora me lembrei que a gente morre. Mas - mas eu também?!

Não esquecer que por enquanto é tempo de morangos.

Sim. (1998a, p. 87, grifos meus)

O vínculo entre narrador e personagem e, do mesmo modo, entre imagem de leitor e personagem é, portanto, da ordem do orgânico, por conter uma dimensão responsivoexotópica estruturante. Dimensão, muitas vezes, indelével, irremediável, que faz com que a experiência do relato não vise à transmissão de saberes, de conhecimentos, mas, ao contrário, seja terreno propício a uma "vivência do real", para um intercâmbio narrativo no qual os participantes se internecessitam: "Vou fazer o possível para que ela [Macabéa] não 
morra. Mas que vontade de adormecê-la e de eu mesmo ir para a cama dormir" (1998a, p. 81). Por essa razão que é possível verificar, no romance clariceano, essa alternância entre o narrar o "eu" e o outro ou entre o narrar o "eu" por meio do outro, uma personalização que não pode se dar no confortável âmbito do isolamento, mas no terreno árido, por vezes doloroso e imprevisível, da interação:

Nestes últimos três dias, sozinho, sem personagens, despersonalizo-me e tiro-me de mim como quem tira uma roupa. Despersonalizo-me a ponto de adormecer.

E agora emerjo e sinto falta de Macabéa. Continuemos:

- É muito caro?

— Eu lhe empresto. Inclusive madama Carlota... (1998a, p. 70-71, grifos meus)

As inúmeras confissões do narrador de $A$ hora da estrela de não estar cônscio das dificuldades para cumprir o rol para ao qual ele existe, isto é, o medo de não dar conta de relatar, interpretar, de exprimir o que pôde apreender de um determinado instante da vida de Macabéa, nos conduz à reflexão que Rebecca Monteiro fez sobre a personagem Joana, do romance Perto do coração selvagem. Para ela, representar essa personagem "equivaleria a torná-la menos viva, menos real, menos intervalar" (2008, p. 25). Movimento semelhante realiza o narrador de Macabéa que, em vários trechos do romance, confessa que a existência e a vida dessa personagem independem de sua vontade. Isso significa, em outros termos, que o processo narrativo que experiencia se constitui para além da experiência mesma de narrar, de relatar ou representar, já que se dá em um espaço de performação no qual narrar o outro (esse outro, mil asas de pássaro batendo numa mão em concha) implica, necessariamente, envolver-se, desnudar-se. Sentir na pele o frenesi desesperado dessas asas e posicionar-se responsivamente diante do que vê, do que sente, do que pretende "narrar".

Mas o trabalho do narrador prossegue, a despeito das aporias que enfrenta, das impossibilidades diante das quais vai adquirindo consciência e que terminam por lhe serem constitutivas. O que aconteceria, para ele, diferentemente, seria mais uma influência da personagem em sua realização como narrador do que o contrário. Vejamos 2 (dois) trechos nos quais essa afirmação poderia se justificar: "Ah pudesse eu pegar Macabéa, dar-lhe 
um bom banho, um prato de sopa quente, um beijo na testa, enquanto a cobria com um cobertor. E fazer que quando ela acordasse encontrasse simplesmente o grande luxo de viver" (LISPECTOR, 1998a, p. 59, grifo meu):

Sim, estou apaixonado por Macabéa, a minha querida Maca, apaixonado pela sua feiúra e anonimato total pois ela não é para ninguém. Apaixonado por seus pulmões frágeis, a magricela. Quisera eu tanto que ela abrisse a boca e dissesse:

_Eu sou sozinha no mundo e não acredito em ninguém (...)" (1998a, p. 68-69, grifo meu)

Ao confessar sua impossibilidade de pegar Macabéa e a independência que a personagem teria em relação a ele, quando afirma que ela não é de ninguém e quando deseja, estranhamente - já que poderia muito bem fazer isso se quisesse e à revelia da vontade da personagem, que ela abrisse a boca e falasse -, percebemos o vínculo exotópico necessário do narrador em relação à personagem. Não somente no que tange à constituição mesma do relato da vida dela, mas no modo como ele narra a si próprio diante da narração de uma alteridade tão "viva, intervalar e real".

A organicidade ou a dimensão orgânica da literatura performática, diante disso e a partir do que podemos formular de significado(s) para a primeira epígrafe deste artigo, residiria nesse lugar da incompletude ou da incapacidade confessável, espaço fértil para a realização de uma escrita movimento, de uma escrita encarnada, "que respira, respira, respira". Ao encarar Macabéa como uma personagem que tem "livre-arbítrio", vida própria, essa voz narrativa se recusa a interpretá-la, prendê-la ou apreendê-la em sua narração. Opta, ao contrário, por não se colocar em um lugar de superioridade em relação a ela, localidade a partir da qual tanto pode ser o influenciado quanto aquele que toma as rédeas do jogo narrativo, porque compreende que sua presença não é plena, mas, ao contrário, precária e ameaçada.

Entendo o termo "incompletude" como palavra-chave na compreensão da relação entre autor-narrador/personagem, especialmente se a lemos à luz do conceito de exotopia. 
O que o autor-narrador sente é a incompletude, porque a escrita performática é movimento, feita de completudes apenas provisórias. Sente isso porque também está diante de uma personagem "viva", que o provoca, estabelecendo uma relação de necessidade, diante dessa escrita viva, performática, que "respira". No bojo dessa reflexão, vale a pena recuperar o que afirma Zumthor, a propósito do termo performance, quando diz que ele: "se refere menos a uma completude do que a um desejo de realização” (2007, p. 33).

Objetivo semelhante (o de não encurralar o discurso, o verbo ou a palavra em mordaças pré-fabricadas) parece perseguir o narrador do romance Água viva - também de Clarice Lispector - que, a partir da metáfora do "passarinho na mão em concha", discorre sobre esse fato terrível que é definir limites (em mãos ou gaiolas) para aquilo que só pode ser pleno na vastidão do espaço e em liberdade:

Segurar passarinho na concha meio fechada da mão é terrível, é como se tivesse os instantes trêmulos na mão. O passarinho espavorido esbate desordenadamente milhares de asas e de repente se tem na mão semicerrada as asas finas debatendo-se e de repente se torna intolerável e abre-se depressa a mão para libertar a presa leve. Ou se entrega-o depressa ao dono pra que ele lhe dê a maior liberdade relativa da gaiola. Pássaros - eu os quero nas árvores ou voando longe de minhas mãos. Talvez certo dia venha a ficar íntima deles e a gozar-lhes a levíssima presença de instante. "Gozarlhes a levíssima presença" dá-me a sensação de ter escrito frase completa por dizer exatamente o que é: a levitação dos pássaros. (1998, p. 45-46, grifo meu)

Essa relutância em se valer de uma trajetória narrativa excessivamente controlada obsessão em manter algo que é vivo na finitude sufocante das "mãos” - em favor de outra mais corpórea, mais processual, ${ }^{6}$ dialoga com um dos fundamentos teóricos da performance ${ }^{7}$

\footnotetext{
${ }^{6}$ Baseio essa oposição entre um tipo de narrativa mais corpórea e outra mais controlada na distinção, feita por Zumthor, entre as noções de totalidade e globalidade. Para ele, a primeira designaria um conjunto orgânico dado por fechado e a segunda conotaria abertura, progressividade, energia movente, menos convenção (cf. ZUMTHOR, 2007, p. 101-102).

${ }^{7}$ Segundo Melendi, “a palavra performance incomodou os artistas, agora performers, para quem esse termo despolitizava o trabalho, aproximando-o do teatro e associando-o com a representação e o entretenimento” (2005, p. 84). 
que a insere em uma localidade afastada da do teatro, ${ }^{8}$ nos termos apresentados por Renato Cohen. Segundo ele, o teatro caminharia "segundo as proposições da cena aristotélica," apoiada na representação - convenção" (2004, p. 139). Mais que representar, ou mesmo apresentar, narrar performaticamente passaria a ter uma conotação mais próxima daquela traduzida pelo termo "experiência", entendido, aqui, como processo corporificado que contempla a possibilidade de uma vivência narrativa processual ou em trânsito. Diferentemente de um modo de narrar que lida com o escritural como instância coisificada (o objeto) ou, ainda, como escrita-produto. ${ }^{10}$

Enunciar performaticamente significaria, nesses termos, atribuir uma dimensão corporificada à figura do narrador. Não o entender apenas como mais um “elemento” da narrativa, mas como uma instância ficcional que narra porque vive a narração, porque a sente e se projeta nela, porque se desnuda ao construí-la e se definha ao finalizá-la. Não necessariamente porque protagoniza, em uma primeira instância, a experiência que narra, problematização que faz Silviano Santiago no texto "O narrador pós-moderno”, mas porque se projeta visceralmente na ação de narrar o alheio - sendo, portanto, paradoxalmente, sujeito ativo de dita experiência e, consequentemente, também um de seus personagens - por se envolver com o narrado.

\footnotetext{
${ }^{8}$ Vale relativizar, no entanto, que a cena teatral contemporânea, especialmente as que se apóiam no processo colaborativo (um bom exemplo é o trabalho do grupo paulista Teatro da Vertigem) como princípio teórico e prático que norteia a elaboração do texto espetacular, já não considera mais essas espacialidades (palco e público) como instâncias incomunicáveis, "incontamináveis".

${ }^{9}$ Cohen, "o teatro grego, que foi coligido por Aristóteles, institui uma separação espacial, dividindo palco e plateia. Nesse espaço se dá a representação, suportada por uma convenção teatral. Não há ligação física entre os dois topos durante a representação; o objetivo é, através da representação, levar o espectador à empatia com o que está se mostrando e a uma consequente catarse psíquica" (2004, p. 123).

${ }^{10}$ Suspeito que vivenciar o processo escritural como ato performático - experiência única, singular e irrepetível poderia ser uma das razões que possivelmente justificaria o rechaço de Clarice em retomar a leitura e a escrita (revisões) de seus textos. Na obra $A$ descoberta do mundo, no texto "Conversas", ela assume isso ao afirmar: "Guimarães Rosa disse que, quando não estava se sentindo bem em matéria de depressão, relia trechos do que já havia escrito. Espantaram-se quando eu disse que detesto reler minhas coisas" (1999, p. 136).
} 
Implicação corpórea no texto materializada por meio de uma voz narrativa que se constitui como elemento-chave da experiência estética. Voz que conforma uma dimensão orgânica do relato como tentativa de aproximação do "campo do indizível” (MIRANDA, 2007, p. 354), termo que usa Ana Miranda para se referir à linguagem do romance $A$ hora da estrela de Clarice Lispector, ao que certos tipos de escrita, como as "escritas à beira" parecem querer, de algum modo, tangenciar. Tentativa semelhante à empreendida pela escrita performática que desfavorece “as leituras que se alojam na vertente da compreensão" (2007, p. 354), já que compreende o real como algo que constantemente nos escapa e nos ultrapassa, tal e como afirma o narrador clariceano sobre sua relação com o real e, do mesmo modo, a propósito da dificuldade que sente em lidar com uma personagem buliçosa como Macabéa.

A escrita literária performática, nesse caso específico, via narração performática, entendida como arte vivencial, se comportaria como uma espécie de resposta estética aos fundamentos que norteiam a noção de arte representativa, essa que contempla o desejo de apreensão, espécie de ambição totalizadora, do real. Tentativa empreendida, em parte, pelo poeta Ollan, no conto de Borges, aqui antes mencionado, que constrói a primeira versão de uma ode de louvor ao rei tomando a imitação de modelos retóricos e de experiências de vida como estética para a composição textual. Opção escritural estreitamente vinculada à metáfora do espelho, presente a ele oferecido pelo monarca, que, apesar de conter, pormenorizadamente, os grandes feitos e lutas norueguesas, não revelava o texto que o rei esperava que ele fizesse. Na verdade, não provocava efeito algum no leitor/espectador. Efeito nenhum. No entanto, ao receber uma adaga como terceiro presente, com ela o poeta se mata, após ter conseguido construir o poema por excelência. Um poema que não podia existir, mas que encerrava, em apenas um verso, a perfeição e a beleza, o qual nenhum dos dois mal conseguia proferir, tamanho o deslumbramento pelo qual estavam tomados.

Expiada a vida do poeta, a narrativa ganha, finalmente, força (perfeição?). Expiada a vida de Macabéa, tolhida está a possibilidade de o narrador continuar o relato. Findada a vida da personagem, finda, junto, o desejo do narrador em narrá-la. Mas o romance, no 
entanto, ali está. Performático. Resultado da busca de uma narração que se dá por meio de uma experiência narrativa como processo corporificado (na medida em que me aproximo dela, me aproximo de mim mesmo e sucumbo por essa mesma razão - diria Ollan - ou na medida em que contemplo essa possibilidade - narrador clariceano). Não se trataria, assim, na escrita performática, de uma experimentação sintática ou formal, pelo menos não só. Pode ou não estar e ir junto, mas essa experimentação está relacionada com encontrar um tom que permita uma espécie de transposição de vivências, como acontece com Ollan que, finalmente, encontra uma forma de versificar a Beleza, um algo mais, que acaba produzindo sua morte e o desterro do rei.

E se a nomenclatura "escrita performática" é paralela àquela da escrita do movimento, do instante, seus princípios só poderiam partir de uma concepção teórica não perspectivada por noções como "fixidez", “ordenação”, “organização” e “previsibilidade”. Isso porque "a obra de Clarice nos convida a observar o texto (e o mundo) para além das ideias de fim, começo, sentido ordem e evolução (...). Em sua escritura, o sentido é vivido apenas uma vez, no momento presente" (MONTEIRO, 2008, p. 13-14). Assim como, a partir de um único verso, terceira e última tentativa do poeta, escritor e monarca, no conto borgesiano, conhecem, enfim, a Beleza.

A propósito dessa temporalidade eminentemente presentificada, vale lembrar a declaração que faz o narrador de $A$ bora da estrela, que condiz com o que Rebecca Monteiro expressa e com a ideia de presentificação procedimental inerente à realização da escrita performática:

Quero acrescentar, à guisa de informações sobre a jovem e sobre mim, que vivemos exclusivamente no presente pois sempre e eternamente é o dia de hoje e o dia de amanhã será um hoje, a eternidade é o estado das coisas neste momento. (1998a, p. 18, grifo meu) 
Essa temporalidade "momento presente" que a escrita clariceana apresenta, inclusive em outras de suas obras, como Água viva, por exemplo, espécie de teorização sobre o fazer literário no momento mesmo de sua realização, dialoga com a noção de "aqui e agora" (COHEN, 2004, p. 31) das artes performáticas. Noção cuja força-motriz surge de uma contaminação mútua, de uma oscilação constante e imprevisível entre os agentes da escrita, tais como narrador e imagem de leitor que experimentam a narração (leitura ou construção) como vivência, como local construtor, revisor, de ensaio de identidades (ficcionais ou não; construídas ou não). Isso ocorre porque a história se apresenta como se não estivesse em um lugar previamente definido. Ela se estrutura, ao contrário, no processo escritural, em uma instância tempo-espacial presentificada: os "instantes-já"11 clariceanos.

Podemos perceber, igualmente, a importância desse experenciar a narrativa ou a escritura no momento de seu fazer, de sua feitura, no pequeno texto "Como é que se escreve?", presente no livro $A$ descoberta do mundo, no qual Clarice Lispector declara:

Quando não estou escrevendo, eu simplesmente não sei como se escreve. E se não soasse infantil e falsa a pergunta das mais sinceras, eu escolheria um amigo escritor e lhe perguntaria: como é que se escreve?

Por que, realmente, como é que se escreve? que é que se diz? e como dizer? e como é que se começa? e que é que se faz com o papel em branco nos defrontando tranquilo?

Sei que a resposta, por mais que intrigue, é a única: escrevendo. Sou a pessoa que mais se surpreende de escrever. E ainda não me habituei a que me chamem de escritora. Porque, fora das horas em que escrevo, não sei absolutamente escrever. Será que escrever não é um ofício? Não há aprendizagem, então? O que é? Só me considerarei escritora no dia em que eu disser: sei como se escreve. (1999, p. 156-157, grifo meu)

${ }^{11}$ Essa expressão aparece no romance Água viva, e assim a define Clarice Lispector: "Mas o instante-já é um pirilampo que acende e apaga, acende e apaga. O presente é o instante em que a roda do automóvel em alta velocidade toca minimamente no chão. $\mathrm{E}$ a parte da roda que ainda não tocou, tocará num imediato que absorve o instante presente e torna-o passado. Eu, viva e tremeluzente como os instantes, acendo-me e me apago, acendo e apago, acendo e apago. Só que aquilo que capto em mim tem, quando está sendo agora transposto em escrita, o desespero das palavras ocuparem mais instantes que um relance de olhar. Mais que um instante, quero o seu fluxo" (1998, p. 15, grifo meu). 
Espacialidade e temporalidade processuais que fundam o confronto mais orgânico e talvez mais significativo entre texto literário, narrador, personagem e sua imagem de leitor, pois, afastado de uma racionalização, inclusive verbalizada, dessa fruição, consegue ser experiência corpórea inapelavelmente presente na vibração singular de cada movimento escritural, de cada momento de leitura dessa escrita. A propósito disso, vale recuperar uma afirmação do narrador de Água viva e outras duas de A hora da estrela:

Estou consciente de que tudo o que sei não posso dizer, só sei pintando ou pronunciando sílabas cegas de sentido. E se tenho aqui que usar-te palavras, elas têm que fazer um sentido quase que só corpóreo, estou em luta com a vibração última. Para te dizer o meu substrato faço uma frase de palavras feitas apenas dos instantes-já. Lê então o meu invento de pura vibração sem significado senão o de cada esfuziante sílaba. (LISPECTOR, 1998, p. 11)

Eu não inventei essa moça [Macabéa]. Ela forçou dentro de mim a sua existência. (1998a, p. 29-30)

Com esta história eu vou me sensibilizar, e bem sei que cada dia é um dia roubado da morte. Eu não sou um intelectual, escrevo com o corpo. E o que escrevo é uma névoa úmida. As palavras são sons transfundidos de sombras que se entrecruzam desiguais, estalactites, renda, música transfigurada de órgão. (1998a, p. 16) (grifos meus)

O percurso discursivo traçado pelo narrador de $A$ bora da estrela não se dará, nessa perspectiva, como totalidade, mas se efetivará por meio de um deslizamento intermitente, intersticial, que busca menos o significar do que o experienciar, menos o objeto do que a ação, menos o todo do que a energia movente, o fluxo, a vibração do momento. A propósito dessa afirmação, vale recordar a pergunta que lança Lispector, fundamental para o desenvolvimento da hipótese da existência de uma escrita performática, em seu romance Água viva: "A palavra é objeto?” (1998, p.12). Tal e como apreendo de uma afirmação que Clarice Lispector fez, em um trecho de sua obra $A$ descoberta do mundo que, interessantemente, parece querer definir o conceito de romance a partir dessa noção de vivência, num 
esforço para desprender-se de "molduras" ou "mãos em concha" que definem previamente a qualidade daquilo que pulsa dentro delas (no caso, aqui, o discurso literário):

\section{ROMANCE}

Ficaria mais atraente se eu o tornasse mais atraente. Usando, por exemplo, algumas das coisas que emolduram uma vida ou uma coisa ou um romance ou um personagem. É perfeitamente lícito tornar atraente, só que há o perigo de um quadro se tornar quadro porque a moldura o fez quadro. Para ler, é claro, prefiro o atraente, me poupa mais, me arrasta mais, me delimita e me contorna. Para escrever, porém, tenho que prescindir. A experiência vale a pena-mesmo que seja apenas para quem escreveu. (1999, p. 433, grifos meus)

O nível de enunciação narrativa de $A$ hora da estrela está entrecortado por essa disposição fugidia do narrador, marca dessa experiência entre o texto e quem o narra que, talvez, se relacione com a ideia de "prescindir", a que faz menção Lispector, no fragmento acima. Sua presença se transfigura a todo instante. Entre ausências e sucessivos afastamentos na tessitura da narração de Macabéa, aos quais se submete e nos submete, o narrador vai revelando esse caráter dispersivo da configuração discursiva do romance que ganha contornos, desfazendo-os a todo instante. Tal como um vaga-lume que se acende e se apaga, que se acende e se apaga... Passeio movediço entre o narrar o outro e o narrar a si mesmo. Entre narrar-se ao narrar o outro. Entre expor dispersões necessárias para a conformação de uma escrita literária que quer ser menos um ato solitário do que um "agenciamento coletivo da enunciação" (PEDRON, 2006, p. 33).

Vejamos a explicitação desse vínculo fraternal, pacto performático entre escritura e vida, em umas das falas finais do narrador de $A$ bora da estrela. Ao fazer expirar seu discurso narrativo, em função da morte "física" de Macabéa, recorda-se, estupefato, da própria morte, a despeito do tempo cíclico das estações que se evidencia na temporada de morangos. Constatação que faz recordar uma reflexão bakhtiniana que, ao abordar a morte, assevera que, quando o outro morre, morre igualmente a possibilidade de eu ter a compreensão de mim mesmo que o outro me oferecia enquanto me encontrava vivo, enquanto alteridade para mim. (2003, p. 95-96). Precisamente o que acontece em A hora da estrela: 


\section{Macabéa me matou.}

Ela estava enfim livre de si e de nós. Não vos assusteis, morrer é um instante, passa logo, eu sei porque acabo de morrer com a moça. Desculpai-me esta morte. É que não pude evitá-la, a gente aceita tudo porque já beijou a parede. Mas eis que de repente sinto o meu último esgar de revolta e uivo: o morticínio dos pombos!!! Viver é luxo. (LISPECTOR, 1998a, p. 86, grifo meu)

Por estar apoiado em uma base multifacetada, em contraposição a outra monologar, cuja rigidez da hierarquização de sua estrutura impediria a realização de um devir interacional de vozes discursivas, de um nomadismo tempo-espacial da narração literária, de movimentos desterritorializadores que imprimem vida à escrita, o discurso narrativo de $A$ bora da estrela define-se no contraponto entre o "ser" diante do outro e o “ser" pelo outro. Em outras palavras: o narrar a si próprio, ao textualizar o outro. Para o narrador de $A$ hora da estrela, nesse sentido, representar significaria, necessariamente, um sair de si, estando em si. O exotópico. Uma entrega ativa que ele exigirá de si e da imagem de leitor que aparece no romance: "Transgredir, porém, meus próprios limites me fascinou de repente. E foi quando pensei em escrever sobre a realidade, já que essa me ultrapassa” (1998a, p. 17).

Não caberia, nesse movimento, entender a escrita performática a partir de uma ideia de Arte que Adorno chamou burguesa e teológica, cujo intuito maior era o de "dar bons conselhos ao real e ao estabelecido". Suas bases estariam fundadas, ao contrário, no que Adorno, em 1969, lucidamente põe fé: “As obras de arte saem do mundo empírico e criam outro mundo com essência própria e contraposta ao primeiro, como se este novo mundo tivesse consistência ontológica”. ${ }^{12}$

\footnotetext{
${ }^{12}$ ADORNO, s/d, s/p: "Las obras de arte se salen del mundo empírico y crean otro mundo con esencia propia y contrapuesto al primero, como si este nuevo mundo tuviera consistencia ontológica".
} 
Ainda que o percurso narrativo empreendido pelo narrador de $A$ bora da estrela possa ser qualificado como forjado ou como mero "artifício metaficcional", de "espontaneidade figurada", "entrada no domínio da metadiscursividade” (MONTEIRO, 2008, p. 57), isso não isenta a escrita clariceana de conter o que Sousa lucidamente apontou: uma “intensidade da entrega [que] pressupõe a inclusão da figura do eu (o trabalho sobre si mesmo) no processo de pesquisa que é a escrita” (SOUSA apud MONTEIRO p. 59-60).

A escrita, nesse caso, deixaria de ser uma fraude, em relação à realidade, até porque, como já dito anteriormente, isso não é, em absoluto, uma de suas pretensões, e passaria a ser (e a se interpor) um "espaço de performação". Lugar de encenações de "eus", (encenação tomada, aqui, no sentido de colocar em cena): o eu do autor, do narrador, da personagem, ou o eu da imagem de leitor criada no romance. O nosso. Unidos por uma ponte fluida na qual um é parte do outro, a partir da qual um reverbera no outro. Organicidade resultante da mobilização que o "transgênero performático" imprime ao texto por meio da "ação”, do "movimento" e das "sensações” (RAVETTI, 2003b, p. 40).

Graciela Ravetti, em seu artigo "O corpo na letra: transgênero performático”, reflete sobre a possibilidade da ampliação da conceituação dos termos arquivo, escritura e gênero, que partiriam não somente da consideração da letra impressa, mas também das marcas do corpo na letra. Isso acarretaria uma mudança na nomeação desses conceitos, que poderiam ser, então, elaborados a partir do prefixo "trans" que, segundo essa teórica, "se refere a 'movimento para além de'; 'através de', 'posição para mais além de'; 'posição ou movimento de passagem'; 'intensidade"' (2003a, p. 85-86). Um prefixo que, portanto, pudesse favorecer a percepção do acréscimo de sentido que a projeção do corpo oferece à letra.

Mas, ainda que o narrador clariceano, a partir de uma relação exotópica com a personagem da obra, dada num espaço de performação, acabe explicitando os contornos linguísticos da ficção que narra, seu status ontológico ou a autoconsciência do texto que narra, ele não se posiciona de modo centralizador e manipulador, em relação à sua produção. Ele admite suas precariedades por revelar a todo o tempo, por exemplo, sua dimensão orgânica, sua projeção corpórea na letra, marca do transgênero performático, que 
necessita da alteridade da personagem e da imagem de leitor subjacente à narrativa que constrói para sustentar a tarefa de narrar. Para sustentar o próprio estatuto da narrativa, já que ela é passarinho vivo. Esse narrador perde, portanto, exclusividade com respeito à autoridade discursiva, porque narra a partir de uma lógica interacional, comunicacional e corpórea e porque parte da ideia de literatura política, nos termos de Rancière.

Para esse filósofo francês, "a arte está diretamente relacionada com uma divisão política do sensível enquanto forma de experiência autônoma” (2005a, p. 22). Autonomia que equidista da do fazer artístico oficializado pela Modernidade, porque, agora, tem a ver com uma experiência sensível, consubstancial ao estatuto do texto como política da escrita, que se encontra fortemente conectada a uma ligação comunitária, coletiva.

A explicitação do caráter representacional da ficção que o narrador performático realiza difere, desse modo, de uma perspectiva narcisística e se volta para outra mais coletiva, mais solidária, porque a construção textual considera os processos internos, imaginativos ou psicológicos do narrador, e não somente os da personagem. O leitor tem diante de si um texto a ser lido, completado, organizado, etc., cuja autoconsciência não se dá apenas no plano linguístico-textual, mas no plano orgânico-corpóreo de um narrador que constrói uma narrativa porque a vive, porque a sente e se implica com o narrado e com os sujeitos envolvidos nessa narrativa: ele, a personagem e a imagem de leitor subjacente a essa ficção. Daí o caráter performático.

Justamente nesse ponto, no qual a literatura deixaria de ser o panteão referência da ficcionalidade, é que percebo a importância da discussão sobre a relação entre literatura e experiência estética e pessoal, entre textualidade e vivência. Até porque, valendo-me das palavras do narrador de $A$ bora da estrela, quando discorre sobre a incapacidade de Macabéa em "enfeitar a realidade", declara: "Mas não sabia enfeitar a realidade. Para ela a realidade era demais para ser acreditada. Aliás, a palavra 'realidade' não lhe dizia nada. Nem a mim, por Deus” (LISPECTOR, 1998a, p. 34). 
A narração literária performática não teria como pretensão tomar o relato como um meio de transmitir conhecimentos, de dar conselhos; em outros termos, a via de realização da "comunicabilidade da experiência" a que faz referência Walter Benjamin em seu célebre texto sobre o narrador. Ao atribuir essa capacidade aos narradores da tradição oral que, diferentemente dos narradores dos romances, estariam autorizados e capacitados a discorrer sobre a experiência, o filósofo alemão parece querer argumentar sobre uma provável impossibilidade da transmissibilidade da experiência a partir da produção literária do romance, já que o romancista se encontra segregado e, por isso mesmo, "não pode mais falar exemplarmente sobre suas preocupações mais importantes” (1994, p. 201).

Mas se o ato de narrar a "experiência" de outrem - no caso, a história de Macabéa - motiva o narrador de $A$ hora da estrela a construir experiências sobre si próprio, a narrar a si próprio, levando-o a problematizar seu lugar no mundo, não seria de todo coerente rotular o romance como localidade segregadora ou negar sua potência impulsionadora de experiência. Para além de uma transmissão pura e simples, a narrativa performática propicia o desencadeamento de novas experiências, durante a construção do relato ou da leituravivência da experiência alheia (a de Macabéa, por exemplo), conformando "agenciamentos coletivos de experiências" a partir dos quais um suscitaria a realização do outro e, assim, sucessivamente.

No texto "O narrador pós-moderno", cujas ideias se baseiam, precisamente, no texto "O narrador", de Walter Benjamin, Silviano Santiago parece defender também o ponto de vista da legitimidade do narrar a experiência somente por aqueles que as vivenciaram. O que o performático oferece a essa discussão sobre a relação entre experiência e literatura, no entanto, para além de uma noção de legitimidade no e do ato narrativo, é ser potência propulsora de experiência. Relatando e vivenciando a história de Macabéa, o narrador desse romance vai se construindo e, de certo modo, convidando a imagem de leitor dessa obra, (desafiando-o, numa arena literária) a se "construir" também. Vejamos um exemplo claro disso, a partir do uso, pelo narrador, da expressão "quanto a 
mim", que parece significar um convite do tipo "e quanto a você?" a essa imagem de leitor que podemos depreender do romance clariceano:

A datilógrafa vivia numa espécie de atordoado nimbo, entre céu e inferno. Nunca pensara em “eu sou eu”. Acho que julgava não ter direito, ela era um acaso. Pensando bem: quem não é um acaso na vida? Quanto a mim, só me livro de ser apenas um acaso porque escrevo, o que é um ato que é um fato. (LISPECTOR, 1998a, p. 36, grifo meu)

$\mathrm{Na}$ verdade saía do escritório sombrio, defrontava o ar lá de fora, crepuscular, e constatava então que todos os dias à mesma hora fazia exatamente a mesma hora. Irremediável era o grande relógio que funcionava no tempo. Sim, desesperadamente para mim, as mesmas horas. Bem, e daí? Daí, nada. Quanto a mim, autor de uma vida, me dou mal com a repetição: a rotina me afasta de minhas possíveis novidades. (1998a, p. 41, grifo meu)

Quisera eu tanto que ela abrisse a boca e dissesse:

_ Eu sou sozinha no mundo e não acredito em ninguém, todos mentem, às vezes até na hora do amor, eu não acho que um ser fale com o outro, a verdade só me vem quando estou sozinha.

(...)

Quanto a mim, só sou verdadeiro quando estou sozinho. Quando eu era pequeno pensava que de um momento para outro eu cairia para fora do mundo. (1998a, p. 68-69, grifo meu)

Via-se perfeitamente que estava viva pelo piscar constante dos olhos grandes, pelo peito magro que se levantava e abaixava em respiração talvez difícil. Mas quem sabe se ela não estaria precisando de morrer? Pois há momentos em que a pessoa está precisando de uma pequena mortezinha e sem nem ao menos saber. Quanto a mim, substituo o ato da morte por um seu símbolo. Símbolo este que pode se resumir num profundo beijo mas não na parede áspera e sim boca-a-boca na agonia do prazer que é morte. Eu, que simbolicamente morro várias vezes só para experimentar a ressurreição. (1998a, p. 83, grifo meu)

A performatividade da narração em $A$ hora da estrela parece estar fundada, portanto, no devir intenso e fraternal entre corporeidades propulsoras ou criadoras de textualizações que fazem estremecer as significâncias pelo uso de signos não-coisificados, signos mais 
com potência de força, impulso, demanda, que plenos de sentidos previamente dados: "Juro que esse livro é feito sem palavras. É uma fotografia muda. Este livro é um silêncio. Este livro é uma pergunta” (1998a, p. 16-17). Signos cujos limites de significação, de interpelação são colocados, a todo tempo, em xeque. Ser, não ser. Desdobramentos sucessivos em busca de algo que nos escapa, cada vez que dele nos aproximamos (narrador e imagem de leitor). Por tudo isso é que a palavra é dita em função de um agora e é tomada como um acontecimento, já que, conforme a segunda epígrafe deste artigo, "o tudo é um oco nada". Daí a chance de o verbo ser relativizado, o que abre precedente para ser, uma e outra vez retomado; uma e outra vez revisto; uma e outra vez revisitado, em um espaço de performação exotópico; portanto, plural e coletivo. Até porque essa abertura para a mudança, para a transfiguração - não no sentido do aperfeiçoamento, mas de uma transformação - constitui-se como uma de suas premissas básicas de existência, de permanência.

\begin{abstract}
With this article I intend outline the performative trajectory drawn by the narrator of A hora da estrela (1977), written by Clarice Lispector. The performative narration is pronounced throughout the book, which pluralizes the work's narrative configuration by forcing, at all times, the incorporation of other voices on the establishment of the literary text as a unity, even though this unity is taken by impossibility ("o oco nada") and incompleteness. An example of these voices would be the one belonging to a reader to whom the romance's narrator refers at times and with whom he tries to divide the responsibility of the reporting the experience of narrating the life of the character Macabéa.
\end{abstract}

KEYWORDS: Literary writing; Performance; Performative narrator; $A$ bora da estrela; Clarice Lispector.

\title{
REFERÊNCIAS
}

ADORNO, Theodor W. Posição do narrador no romance contemporâneo. In: - Notas de literatura I. Tradução de Jorge Almeida. São Paulo: Duas Cidades; Editora 34, 2003. p. 55-63.

BAKHTIN, Mikhail. Estética da criação verbal. Tradução de Paulo Bezerra. 4. ed. São Paulo: Martins Fontes, 2003. 
BENJAMIN, Walter. O narrador: considerações sobre a obra de Nikolai Leskov (1956). In: . Magia e técnica, arte e politica: ensaios sobre literatura e história da cultura. v. 1. Tradução de Sérgio Paulo Rouanet. São Paulo: Brasiliense, 1994. p. 197-221.

CASANOVA, Vera. O corpo-objeto de Hélio Oiticica. In: RAVETTI, Graciela; ARBEX, Márcia (Org.). Performance, exílio, fronteiras: errâncias territoriais e textuais. Belo Horizonte: Departamento de Letras Românicas, Faculdade de Letras/UFMG: PosLit, 2002. p. $227-$ 232.

COHEN, Renato. Performance como linguagem. São Paulo: Perspectiva, 2004.

HALL, Stuart. A identidade cultural na pós-modernidade. 9. ed. Tradução de Tomaz Tadeu da Silva e Guacira Lopes Louro. Rio de Janeiro: DP\&A, 2004.

LISPECTOR, Clarice. A descoberta do mundo. Rio de Janeiro: Rocco, 1999. - Água viva. Rio de Janeiro: Rocco, 1998. . A bora da estrela. Rio de Janeiro: Rocco, 1998a.

MELENDI, Maria Angélica. Performances clandestinas / performances públicas: regras, rituais, símbolos In: ROLLA, Marco Paulo; HILL, Marcos (Org.). Manifestação Internacional de Performance - MIP. Belo Horizonte: Centro de Experimentação e Informação de Arte, 2005. p. 80-91.

MELIM, Regina. Performance nas artes visuais. Rio de Janeiro: Jorge Zahar, 2008.

MIRANDA, Ana Augusta W. R. de. Uma incidência do corpo em Clarice Lispector: a simplicidade orgânica de Macabéa. In: SOUBBOTNIK, Olga Maria; SOUBBOTNIK, Michael Alain (Org.). O corpo e suas fic(xa)ções. Vitória: PPGL/MEL, 2007. p. 354-358.

MONTEIRO, Rebecca Pedroso. Em função do agora: aproximações entre literatura e política em Clarice Lispector. Orientador: Wander Melo Miranda. 2008. Tese (Doutoramento em Estudos Literários) - Faculdade de Letras, Universidade Federal de Minas Gerais, Belo Horizonte, 2008. $215 \mathrm{p}$.

PEDRON, Denise Araújo. Um olhar sobre a performatividade na cultura contemporanea: a performance como conceito e a produção artística de Diamela Eltit. 2006. Tese (Doutorado em Estudos Literários) - Faculdade de Letras, Universidade Federal de Minas Gerais, Belo Horizonte, 2006. $173 \mathrm{p}$.

PEREIRA, Maria Antonieta. Ricardo Piglia y sus precursores. Tradução de Adriana Pagano. Buenos Aires: Corregidor, 2001.

PONTIERI, Regina. Clarice Lispector: uma poética do olhar. Cotia/SP: Ateliê, 1999. 
RANCIÈRE, Jacques. Sobre politicas estéticas. Traducción de Manuel Arranz. Barcelona: Museu d'Art Contemporani de Barcelona, 2005.

RAVETTI, Graciela. O corpo na letra: o transgênero performático. In: CARREIRA, André et al. (Org.). Mediações performáticas latino-americanas. Belo Horizonte: FALE/UFMG, 2003a. p. 81-97.

. Performances escritas: o diáfano e o opaco da experiência. In: HILDEBRANDO, Antônio; NASCIMENTO, Lylei; ROJO, Sara (Org.). O corpo em performance. Belo Horizonte: NELAP/FALE/UFMG, 2003b. p. 31-61.

SANTIAGO, Silviano. O narrador pós-moderno. In: Nas malhas da letra. São Paulo: Companhia das Letras, 2002. p. 38-52.

VIEGAS, Ana Cláudia. Experiência e espetáculo na escrita de si contemporânea. In: CHIARA, Ana Cristina; ROCHA, Fátima Cristina Dias (Org.). Literatura brasileira em foco: o eu e suas figurações. Rio de Janeiro: Casa Doze, 2008. p. 137-149.

ZUMTHOR, Paul. Performance, recepção, leitura (1990). 2. ed. Tradução de Jerusa Pires Ferreira e Suely Fenerich. São Paulo: Cosac Naify, 2007. 